\title{
Environmental stresses and its implications on breeding of brewing barley
}

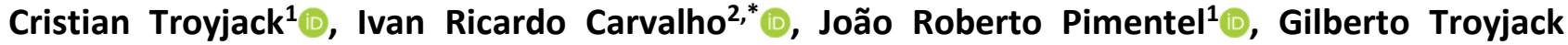

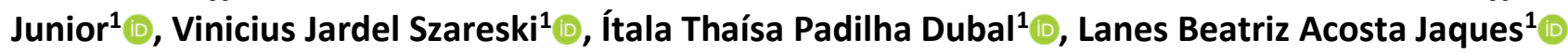 \\ and Giordano Gelain Conte ${ }^{1}$
}

${ }^{1}$ Universidade Federal de Pelotas (UFPEL), Rio Grande do Sul, Brazil. ${ }^{2}$ Universidade Regional do Noroeste do Estado do Rio Grande do Sul (UNIJUÍ), Ijuí, Brazil. *Corresponding author, E-mail: carvalho.irc@gmail.com.

\begin{abstract}
The barley (Hordeum vulgare L.) is a cereal of extreme economic and social importance, due to its wide use, which varies from human and animal consumption, use in chemical and brewing industries. This specie, as for many other, is widely affected by unfavorable environmental conditions, inducing a state of stress in the plants, which, depends on the specie, duration, severity, development stage, affect structure and genotype. Among the main factors causing stress in plants, the abiotic stress stands out, such as high and low temperatures, hydric restriction or excess, salt excess, mineral toxicity and nutritional shortages. The present study has the purpose of expose, as a review, the effects of unfavorable environmental factors in barley and the role of genetic breeding.
\end{abstract}

Keywords: Hordeum vulgare L, hydric restriction, soil flooding, germplasm.

\section{INTRODUCTION}

Most of habitants in the globe depends on gramineous species such rice, wheat, maize, barley, sorghum and oat as sources for most of their diet, to feed cattle and pets (Kellogg, 2001). Among these cereals is barley, which has accompanied humanity within its history, performing a relevant role in the development of agriculture, civilizations and cultures (Ullrich, 2011).

In Brazil, this cereal is cultivated in the Southern region of the country, as well in some Middle-West states such as Goias, Minas Gerais and São Paulo (Ferrari, 2003). In the region of Cerrado, the barley is produced in irrigated system, after the main growing season, what allows the harvest to be realized in dry periods, with scarce rain, resulting in seeds with high quality. In the southern region, production is realized in dry conditions, concentrating in the northern region of Rio Grande do Sul, Center-West of Santa Catarina and Center-Southern of Paraná (Biazus, 2015).

Since its domestication, barley has being grown in many environmental conditions and different production systems, with plenty grain usages. However, the environment conditions where it is grown has direct impact in its production.

At the field, crops are subject to unfavorable environmental conditions, which causes abiotic stresses severely affecting the yield, as well as the distribution of species within different environments. It is estimated that $51-82 \%$ of the yield potential of annual crops is lost due to abiotic stresses, besides that, this damages can be aggravated by the effects of recent climate changes in the globe, as well with prevision of scarcity of drinkable water.

Most of the farming fields in the world is under some inadequate condition to grow crops, what can cause abiotic stress in plants. Some examples of abiotic stresses that a crop may face include water excess, drought, extreme temperatures, salinity, metal toxicity and lack of nutrients in the soil. These factors negatively impact the growth, development, production and grain quality of crops, as well the production of other crops (Soares \& Machado, 2007).

The plants, due to its sessile nature, developed ways to answer and adapt to environmental adversities, as much in physiologic as for molecular levels, which, otherwise, would compromise its normal development, reproductive success and, finally, survival (Apse \& Blumwald, 2003). 
The final purpose of all researches developed in molecular level is to study defensive/tolerant mechanisms to stress in plants that may contribute to the development of technologies and products that allow the generation of more resistant/tolerant plants to stresses and that are economically viable and sustainable (Turchetto, Hartke, Caverzan, \& Turchetto-Zole, 2017). For such, some tools have been used such as genomic, transcriptomic, proteomic, metabolomic, bioinformatics and genetic transformation of plants. Just like the CRISPR technique, which consists of a tool for genetic modification, where it is able to recognize a region and perform the editing, since it works as a DNA "scissors", where it can be cut out as parts of interest in the genome. and edit them according to the research interest (Arend, Pereira, \& Markoski, 2017; Men et al., 2017).

The exploration of the existent genetic variability, by plant breeding, results in increase of productive potential, better quality and in the reduction of losses through better resistance levels or tolerance to environmental stresses (Silveira et al., 2014). Within this context, there is the necessity to develop cultivars that are tolerant for abiotic stresses, in order to guarantee food security. The progress acquired through plant reproduction involves multidisciplinary researchers, such as breeders and biotechnologists.

For the success of the implementation of the barley crop in regions where there are environmental conditions that present slight risks, it must be chosen improved cultivars that will have better answer to these conditions. In this manner, it was developed, in the present study, a literature review of the effects of unfavorable environment factors in the cultivation of barley and the role of genetic reproduction breeding.

\section{GENERAL CHARACTERIZATION OF THE SPECIES}

Barley (Hordeum vulgare L.) is a winter cereal belonging to the family Poaceae, genus Hordeum, from the Triticeae tribe, which includes other agronomically important species such as rye (Secale cereale) and wheat (Triticum aestivum) (Muñoz-Amatriaín et al. 2013). It is a millenarian culture with great socioeconomic importance, just like corn, rice and wheat (Food and Agriculture Organization of the United Nations [FAOSTAT], 2018). With a wide adaptation to growing environments, it was one of the first cereals to be cultivated by man for animal and human nutrition, mainly to obtain malt and for beer production (Galon et al., 2011).

The genus is composed of 32 species, including diploids, tetraploids and hexaploids, where the domesticated barley (Hordeum vulgare) is a diploid plant with seven chromosomes $(2 n=2 x=14)$, strictly autogamous with crosses ratio of less than $1 \%$ (Bellucci et al., 2013).

The variety of species of the Hordeum genus include annual, perennial, autogamous and allogamous. They can be considered cosmopolitan, since they inhabit most temperate areas and extend to arctic and subarctic regions. Some species appears close to the subtropical zone in South America (Southwest Brazil and Northeast Argentina) and the highest concentration of species is found in Southwest Asia and South America (Bothmer, Jacobsen, Baden, Jorgensen, \& Laursen, 1995).

The barley grains have 53 to $67 \%$ starch, 14 to $25 \%$ fiber and 9 to $14 \%$ protein and are classified into two main types: the varieties of two and the varieties of six rows of grains by spike, represented by the covarieties distichum and vulgare, respectively (Oscarsson, Andersson, Salomonsson, \& Åman, 1996; Mayer, Fuke, Nörnberg, \& Minella, 2007; Panizo-Casado et al., 2020).

Barley has been reported to be one of the earliest man-tilled crops, approximately 10,000 years old, at the ancient Mesopotamia, and occurs in most temperate areas (Poets, Fang, Clegg, \& Morrell, 2015) and has since, gained ground in world agriculture. In Brazil, its cultivation is already understood by regions that are not traditionally producers, such as the Cerrado. This was possible due to the research results obtained by Embrapa Cerrados and Embrapa Trigo, which were able to adapt this crop to the edaphic and climatic conditions of the region (Amabile, Capettini, \& Faleiro, 2013).

The total cycle of this cereal is very varied, which depends on the genotype, crop location and date of sowing. In Brazil, the cycle has an average duration of 110 days, while in Australia it can vary from 105 to 157 days (Thomas \& Fukai, 1995; Amabile et al., 2013), which demonstrates its cycle variability according to the place of cultivation.

The inflorescence of the barley is a terminal spike formed by the rachis and by a variable number of spikelets. As in the other species, the spike is characterized by three spikelets per node, originating alternately on opposite sides of the rachis. Each spikelet is formed by two glumes and a flower. The lateral spikelets are sterile in the two-row and fertile types in six-row barley (Reid, 1976).

This crop is morphologically characterized by its spike-shaped inflorescence (Houston et al., 2013), 
possessing a triple spikelet, one central and two sides, and when fertile, presents six seeds per node of the rachis (Ferreira et al., 2016). The individualized spikelets are composed of one or several caryopsis clad with the shell strongly adhered to the pericarp, formed by glumellae (Wrigley \& Batey, 1995).

The barley seed is contained in the caryopsis, being formed by the hull, pericarp, germ, endosperm and aleurone layer (Boom et al., 2006). This last structure is of great importance for the brewing industry, it is responsible for the transport of hormones to the interior of the endosperm and for the accumulation of $\alpha$ and $\beta$-amylase enzymes and $\beta$-glucanases, which act in the production of alcohol (Popinigis, 1985).

The flower is complete with the three stamens and the pistil covered by the palea and lemma (glumellaes). The lemma (extern) may end in an awn or hood. The pistil is composed of the ovary and a bifurcated stigma of variable hairiness. Two lodicles are located at the base of the ovary, and the stamens are made up of anther and filament originating from the base of the ovary.

Barley is reproduced by self-fertilization, with dehiscence of anthers occurring normally before flower opening, often before ear emergence. The rate of cross-fertilization is less than $1 \%$, even in conditions favorable to allogamy (Guerrero, 1999).

Barley seeds harvested at moisture content above $13.5 \%$ should be dried to ensure quality during storage. Otherwise, seeds with high humidity can be rapidly contaminated by fungi (Poulsen, Blaabjerg, Norgaard, \& Ton Nu, 2012). In barley seeds with $14 \%$ water, it is possible to grow Aspergillus spp., being $A$. restrictus and A. glaucus the species that most compromise the conservation of this cereal, as they cause a reduction of vigor and germination, colonizing especially the embryo (Lazzari, 1996).

\section{BARLEY IN BRAZIL}

The Brazilian area destined to agriculture is of approximately $7.6 \%$ of total national territory, which corresponds to an extent of about 66 million hectares (Empresa Brasileira de Pesquisa Agropecuária [EMBRAPA], 2005), however, the projections indicate that for 2029/2030, the crop areas should represent about $10.4 \%$ of the Brazilian territory (Gasques et al., 2020). Within this amount, it is evidenced a large diversity of species being produced, where barley represents a grown area of 103.4 thousand hectares (Companhia Nacional de Abastecimento [CONAB], 2021).

The grains are used to human diet (Mayer et al., 2007), in the composition of flour or flakes for bakery and animal feed, in addition of its main use, which is malt for brewing industries (Badr \& El-Shazly, 2012). This cereal is widely produced in the southern region of Brazil, where the main producing states are Rio Grande do Sul and Paraná, being sowed in fall/winter, sharing fields with wheat, oat and triticale. The barley area in Brazil is close to 100 thousand hectares, however, the southern region of Brazil concentrates most of the production (Narwal, Kumar, Kharub, \& Verma, 2020). Barley is the fourth most sowed cereal in the world, following wheat, rice and corn (FAOSTAT, 2013).

Barley can be classified in two main groups in relation to its destiny and usage, brewing or forage industry. The purpose of the barley for forage may be a viable alternative, since barley is versatile and it has been used in many countries for plenty of animals, including dairy cattle (Juskiw et al., 2020).

In Brazil, barley stands out for the brewing industry, malt commercial production, with $75 \%$ of its production destined to its production destined for commercial malt production (Narwal et al., 2020). For other ends, it has not consolidated due to the lack of competitiveness to other cereals, such as maize, differing from Europe and United States, where barley is widely used as base for animal feed, replacing maize (Boyles, Anderson, \& Koch, 2017).

The area intended to barley production, in Brazil, is small in comparison to other crops as soybean and maize, tending to stabilize in the last years, as observed in Figure 1. The cultivation area was 103.4 thousand hectares in the 2020 harvest, however the same projection remains for the 2021 harvest (CONAB, 2021).

Since the main purpose of barley is for brewing production, growing this grain has some peculiarities to grain quality, which are similar to the ones required for seeds (Jaques et al., 2019). The grains that are presented within the limits fixed by the ordinance no 691 of November 1996 of the Brazilian Ministry of Agriculture, Livestock and Food Supply (Ministério da Agricultura Pecuária e Abastecimento [MAPA]), will be considered below official patterns and must not be used for malt production and brewing ends.

Typical of cold weather, brewing barley has gained space in Cerrado since the end of the 90s, after the development of the first cultivars adapted to the climatic conditions of the region by Embrapa. Today, Cerrado has expanded the area planted with brewing barley, reducing the importation of the cereal in Brazil. However, the Brazilian production of barley for brewing purposes is concentrated in the three 
southern Brazilian states (Rio Grande do Sul, Santa Catarina and Paraná), where factors such as climate, genotype and management are determinants of grain production with quality standards for malting, particularly in relation to germination, size, protein content and grain health (Minella, 2012).

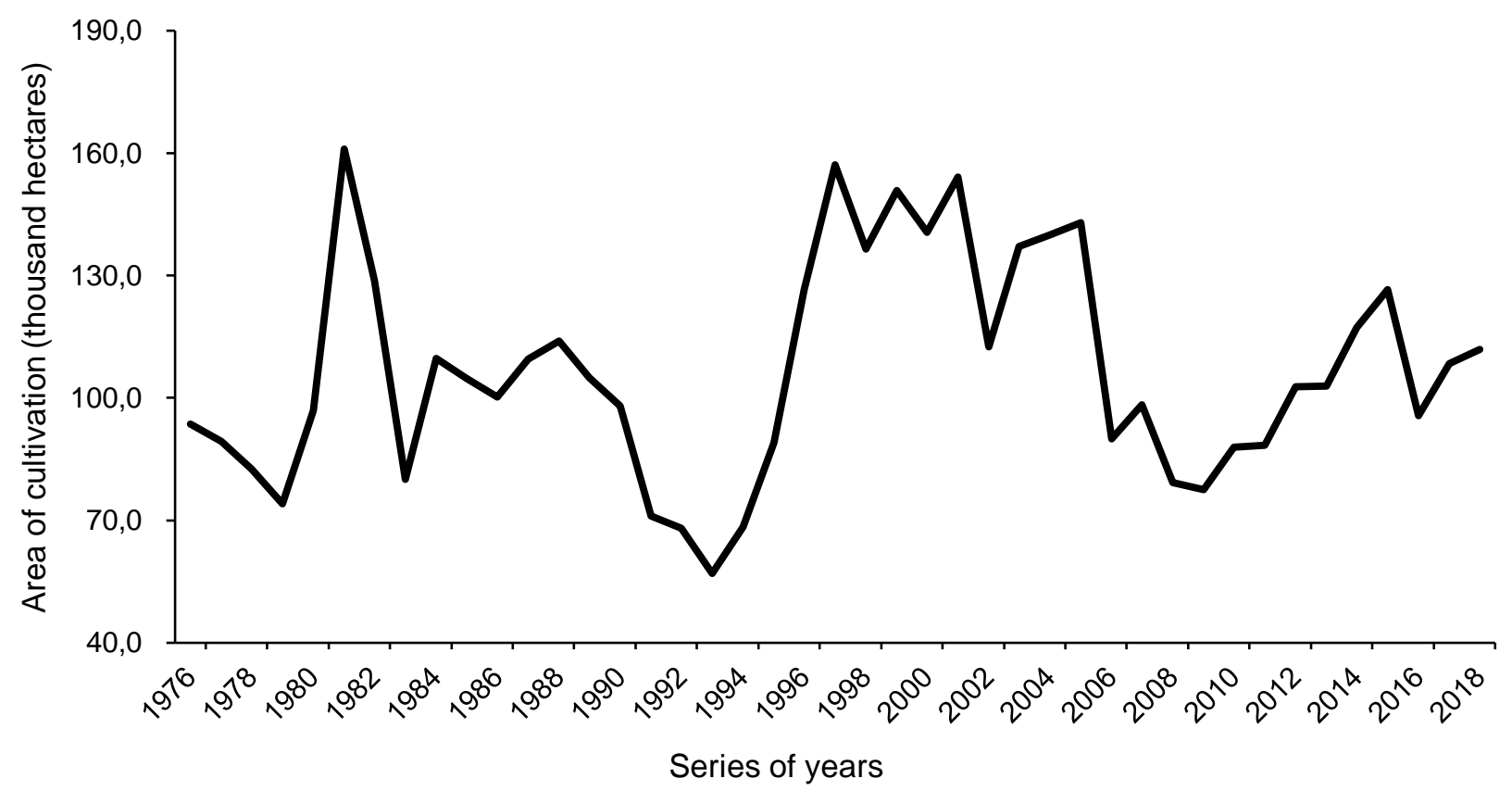

Figure 1. Series of years of the barley cultivation area in Brazil from 1976 to 2018.

Source: Conab, 2018.

From the 1990s there was an increase in the market demand and competitiveness of this species. The average yield of barley in Brazil has increased in recent years (Figure 2A), and this increase can be attributed to genetic improvement and the use of specific genotypes for each growing region. In 2017, barley production reached 282.1 thousand tons, and in 2018 an estimated 323.4 thousand tons of grains (Figure 2B). However, in 2020, barley production was 13.6\% higher than 2018 and the estimate is for a $3 \%$ growth for the 2021 harvest compared to 2020, with Paraná being the main producing state with 62.7 thousand hectares planted. in the 2020 harvest, followed by Rio Grande do Sul with 39.1 thousand hectares (CONAB, 2021).
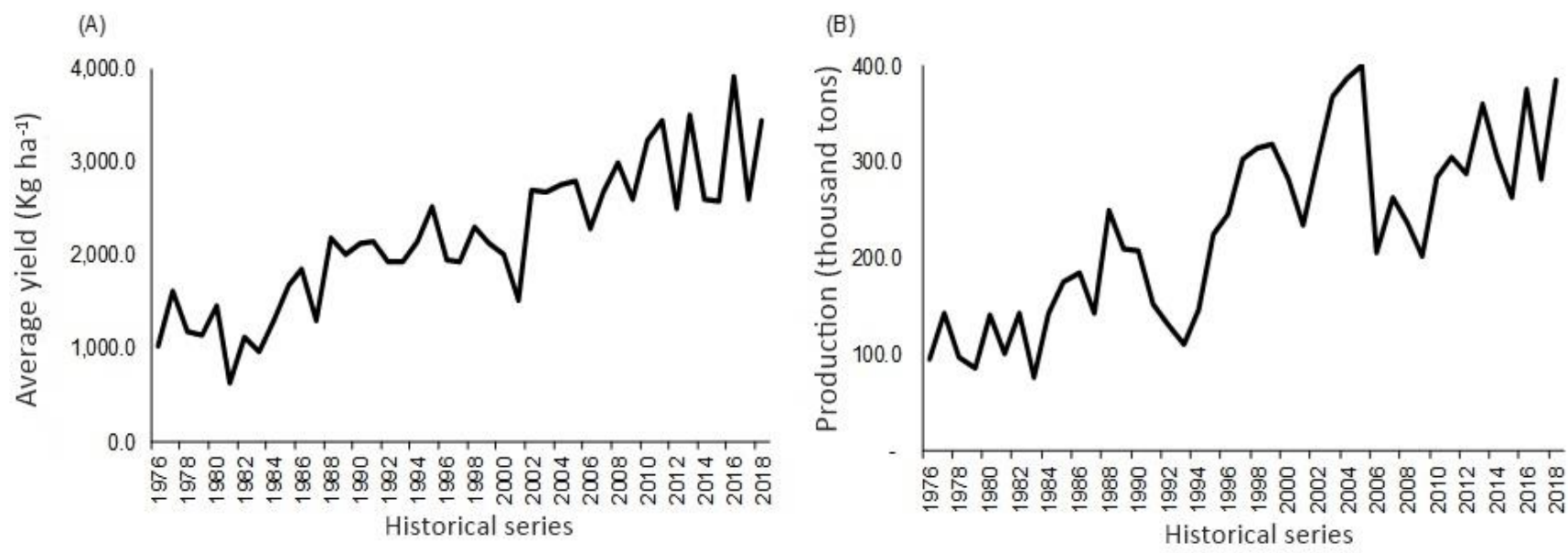

Figure 2. Historical series of years of average yield (A) and production (B) of barley in Brazil from 1976 to 2018. Source: Conab, 2018.

According to Minella (2012), new investments such as the cultivation of varieties adapted to new regions are being developed in order to reduce the dependence of the imports of this cereal, demonstrating that the potential for growth of the barley-malt complex in Brazil is enormous. The choice of most competitive barley for a specific region is a decisive factor for the success of the enterprise. However, the productive sector has a reduced number of cultivars, defined by the brewing companies that buy the production, 
which guarantees for the company a uniformity of the material traded. Thus, the producer is limited to those cultivars that in many cases are not the most productive in the region of their property or do not present characteristics of tolerance to conditions of abiotic stresses.

\section{THE ABIOTIC STRESSES IN BARLEY PRODUCTION}

Abiotic stresses can incisively interfere in the yield of many crops, mainly in species that present low resistance to adverse conditions, such as high and low temperatures, hydric restriction, flooding, toxicity by mineral elements, salts in excess and nutritional deficiencies (Szareski et al., 2018).

In general, the stress can be considered as a significant deflection of the optimal conditions for the crop life, inducing changes in all functional levels of the organism, which, at first may be reversible, but can be permanent (Larcher, 2004). In this manner, aiming to avoid losses occasioned by environmental stresses it is important to comprehend the answer of the plants when facing it, in order to identify a common mechanism of tolerance for the variation of stress conditions (Shanker \& Venkateswarlu, 2011).

The frequency and intensity of the hydric deficiency constitute the most relevant factors to the limitation of the world production. A study revealed that this limitation is responsible for 60 to $70 \%$ of the final yield variation from the optimal.

Since it is the main cause of yield losses in the globe, the development of more adapted genotypes is of primordial importance for the food security (Magalhães, 2011). In this manner, the ability to resist to drought periods is one of the main objectives in breeding programs for the cultivation in semi-arid regions without irrigation or even in other regions that present a history of low water availability.

The drought resistance mechanism can be of three types: avoidance, tolerance and scape of drought. (Begg \& Turner, 1975). The plants avoid drought through stomata closure, roots deepening for water extraction, cell wall thickening and increase in cuticle waxiness to maintain its function. These characteristics are genetically controlled, varying within cultivars. In this manner, the different barley genotypes can present tolerance when surviving to adverse conditions, or susceptibility when suffering growth reduction, which, depending on the stress intensity, may take the plant to death (Cambraia, 2005).

Studies related to drought tolerance or hydric deficiency are getting more evidence, since it is the most complex abiotic stress, of larger effect and the most limiting to food production (Pennisi, 2008). The drought stress occurs due to low water availability in the substrate and due to excessive loss by transpiration in relation to root absorption, where these processes are influenced by environmental factors and by plants characteristics.

The majority of crops possess a growing stage in which the hydric deficiency causes larger reduction in yield. In general, the damage level to the productivity tend to be larger when the stress occurs in the reproductive stage, standing out the beginning of flowering until the inflorescence development, anthesis, fertilization and grain/seed formation.

The resistance to water shortage by plants can occur at different levels, depending on the species, duration, severity, development stage of the plant, organ and especially the genotype in question. Oukarroum, Madidi, Schansker and Strasser, (2007), studying the effect of water restriction in barley accessions, verified differential effect of the stress on growing variables of this cereal. The same way, Cantero, Villar and Fereres (1989) studying the water relations in barley cultivars, in the conditions of the dry semi-arid, verified that the amount of water in the plant decreases throughout the cycle and that the genotype of barley with higher productive capacity maintained less stomatal resistance and greater water potential.

Barley productivity depends on genetic potential and environmental factors that interfere plants performance, especially photosynthesis. The photosynthetic process depends on the interception of the photosynthetically active radiation and its conversion to chemical energy, being this dynamics influenced by several abiotic and biotic stresses, which can reduce the leaf area in peculiar stages of the growth and development of the crop (Lopes \& Lima, 2015). Among these factors are the inadequate soil drainage conditions, which may compromise barley productivity.

The majority of growing fields, for species that produces grains, present soils with adequate draining conditions. However, approximately $6 \%$ of the earth surface can suffer temporary flooding periods, being 33 million hectares with lowlands in Brazil, which approximately 5.4 million hectares are in Rio Grande do Sul (EMBRAPA, 2005).

In front of unfavorable conditions for crop production, flooding may be one of the most frequent due to the occurrence of larger rainfall volumes. In this context, it is possible to occur reduction of oxygen 
availability for the roots due to the slow diffusion of oxygen thru the water (Zabalza et al., 2009), what may affect the plants growth in many vegetal species (Coelho et al., 2013; Rosa et al., 2015). The oxygen shortage due to flooding may compromise the physiologic aspects, carbon assimilation, macronutrients absorption as well suppress roots respiration metabolism (Troyjack, Szarescki, Martinazzo, Aumonde, \& Pedó, 2017).

Under flooding conditions, the oxygen availability in cells becomes low in order to supply aerobic respiration what may result in lack of energy and compromise the vegetal metabolism (Bailey-Serres \& Voesenek, 2008). The soil flooding severely interferes in plants growth, being considered one of the main abiotic stresses, generating reduction in seeds production and harming its chemical composition, physical and physiological integrity (Wang, Liu, Li, \& Chen, 2012). The alterations in the radicular system and reduction in the photoassimilates translocation, as well, reduction in the metabolic activity of plants (Sachs \& Vartapetian, 2007), due to soil flooding, entails the reduction of chlorophyll content and intervenes the efficiency and conversion of luminous radiation to chemical energy (Amarante et al., 2007). In studies with barley plants submitted to soil flooding, Yordanova and Popova (2001), it was found a notable reduction in photosynthesis activity of RuBPC after the flooding treatment.

Other environmental condition that meddle the barley plants development is salinity, due to more than 800 million hectares in the globe ( $6 \%$ of total farming lands) being under the salinity condition (Zhang et al., 2010). The salinity induces serious losses to agriculture production, mostly in arid and semi-arid regions, where about $25 \%$ of the irrigated area finds itself salinized (Food and Agriculture Organization of the United Nations [FAO], 2000). Normally, the solute salts that effectively contribute to salinize the soil consist of the varied proportions of the cations sodium $\left(\mathrm{Na}^{+}\right)$, calcium $\left(\mathrm{Ca}^{2+}\right)$, magnesium $\left(\mathrm{Mg}^{+}\right)$and anions chloride $\left(\mathrm{Cl}^{-}\right)$, sulfate $\left(\mathrm{SO}_{4}^{-}\right)$, bicarbonate $\left(\mathrm{HCO}_{3}{ }^{-}\right)$and, sometimes, carbonate $\left(\mathrm{CO}_{3}^{-}\right)$(Toppa \& Brambilla, 2011)

The tolerance of the crops to the salinity varies (Bischoff \& Warner, 1999), being divided in two distinct groups (halophytes and glycophytes), that are based on its answer to the salts high concentrations. Halophytes are native to saline soils and complete their life cycle in those environments, in the other hand, glycophytes do not have salt tolerance to the same degree as halophytes and, usually, there is a limit salt concentration that starts to inhibit growth, to discolor leaves and reduce dry mass accumulation in plants (Taiz \& Zeiger, 2009). However, some crops belonging to this group can still produce considerable yields at high salinity levels in the soil. This ability to adapt is very useful, allowing the selection of genotypes that are more tolerant and still produce, in cases where low soil salinity cannot be maintained (Tester \& Davenport, 2003).

Researches indicates that the loss of agricultural productivity can reach $50 \%$ due to soil salinity (Sunkar, 2005) of a wide variety of crops of economic importance such as maize (Zea mays L.), rice (Oryza sativa L. ) and barley (Hordeum vulgare L.), which are often subject to saline stress (Sairam \& Tiagi, 2004).

Barley is considered susceptible to soil salinity, because it presents a progressive reduction of growth with the increase in the concentration of salts in the environment, although having indications of more resistant cultivars (Loomis \& Connor, 1992). The reduction of growth due to salinity can be explained by the deviation of energy for the functional maintenance of the tissues, where the decrease in dry mass may reflect the metabolic energy cost associated with adaptation to salinity and reduction in carbon gain (Richardson \& Mccree, 1985).

The effect of salinity on cellular metabolism of plants is a consequence of osmotic stress. The high concentration of solutes in the soil solution leads to a decrease in hydric and osmotic potential, causing soil to retain more water (Gheyi, 2000); and ionic stress, due to the high levels of $\mathrm{Na}^{+}$and $\mathrm{Cl}^{-}$(Willadino \& Camara, 2010), which can cause ionic toxicity and nutritional imbalance.

Another environmental factor that negatively affects crops are inadequate temperature conditions, especially when coupled with another stressor such as water restriction. Water restriction and heat are among the major abiotic stresses that drastically limit crop growth and productivity worldwide (Wang, Vinocur, \& Altman, 2003). In the field of production, the co-occurrence of several unfavorable environmental factors, rather than an individual stress condition, is more detrimental to agricultural production (Mittler, 2006). For example, the combined effects of heat and drought on yield are more damaging than the effects of each stress alone, as seen in sorghum (Craufurd, Flower, \& Peacock, 1993), wheat (Prasad, Pisipati, Momčilović, \& Ristic, 2011) and barley (Savin \& Nicolas, 1996).

Thermal conditions have an effect on the most diverse plant life processes, from seed germination and emergence of seedlings through soil temperature, to the vegetative development and growth of the plant as a whole, through soil and air temperatures (Dellagostin, Martinazzo, Pimentel-Junior, Troyjack, \& Pedó, 2017). High temperatures can cause alteration in the functioning of cell membranes, influencing metabolic 
routes related to respiration and photosynthesis. This environmental factor can modify the physic-chemical properties of thylakoids, compromising the transport of electrons, generating ionic imbalance and the production of reactive oxygen species.

High temperature stress can influence plants with C3 cycle, i.e. barley, which presents the apparent photorespiration, in the quantity of carbon compounds synthesized by photosynthesis. The lower production of assimilates tends to reduce their allocation in seeds, producing lighter seeds and with fewer reserves destined to the resumption of embryo growth. In addition, induces high occurrence of seedlings with inadequate growth, which in the field will present more chance of forming a plant dominated within the total population (Essemine, Ammar, \& Bouzid, 2010).

Soil acidity and aluminum toxicity also limit barley production in important agricultural areas worldwide. The toxicity of aluminum (Al) inhibits the division and elongation of root cells, thus reducing water and nutrient absorption and grain yield (Reid, 1976). In Brazil, toxic levels of Al occur in more than half of agricultural areas, and barley production is limited by this characteristic. Therefore, some level of genetic tolerance to toxic levels of $\mathrm{Al}$ is of great importance for the production of barley in Brazil and other regions of acid soils. Barley cultivars and lines that tolerates toxic levels of $\mathrm{Al}$ or low soil pH were related by (Slootmaker \& Arzadun, 1969; Reid, 1976).

Considering the negative effect of environmental stresses on barley cultivars, plant breeding aiming stress tolerant plants is the most efficient strategy to maintain yield on land prone to inadequate growing conditions. Thus, it is important to identify genetic resources with high tolerance to stress and to understand the mechanisms that contribute to the adaptation to concomitant stresses in the field, such as heat and drought.

\section{BARLEY BREEDING}

Barley has its origin from the Middle East, and it is considered one of the first cereals to be cultivated by humans, around 10.000 years ago. This cereal belongs to the Poaceae family, genus Hordeum, which comprehends 32 species, including diploid, tetrapoid and hexaploid (Bothmer et al., 1995).

Since its domestication, barley has been cultivated in many environmental conditions and different growing systems. The exploration of this variability by breeding activities results in increase in yield potential, quality improvement and reduction of losses through better resistance or tolerance levels to diseases, pests and environmental stresses (Minella, 2012). The barley cultivars registered for cultivation in the 2017 and 2018 growing season, for the States of Rio Grande do Sul, Santa Catarina and Paraná are Anag 01, Ana 02, Danielle, BRS Brau, BRS Caué, BRS Korbel, BRS Quaranta and BRS Sampa, being the three firsts from Fapa-Agrária company and the rest from Embrapa (Minella, 2012).

In relation to plant breeding, the species of this genus form three genic pools, being $H$. vulgare and $H$. spontaneum the primary group, $H$. bulbosum the second and the rest, the third. Since it belongs to the first genic group, $H$. spontaneum has been repeatedly used in breeding programs, by its industrial quality and mainly its tolerance to environmental stresses (Bothmer et al., 1995).

The evolution of barley production systems in the world is supported by the development of cultivars with characteristics of interest to farmers, seed producers and industry. In this context, the selection of cultivars, in a breeding program, with genetic potential for high production and high physiological quality of the grain, which is a requirement for barley production, is important to ensure success in the field, even under unfavorable climatic conditions (Moreno, 2016).

As example from other species, the current genotypes as well the gene banks represent the main sources of genes for barley breeding. The breeder has a wide genetic variability (spontaneous and induced) accumulated over several years of evolution of the crop. The available variation comes from the natural selection and the action of humans throughout the years of cultivation in the most diverse edaphoclimatic conditions, production usage and a century of scientific genetic improvement (Minella, 2012).

Improving crops tolerance to inadequate growing conditions is the most efficient strategy for maintaining yields in regions that are under the risk of environmental adversities. Thus, it is important to identify those genetic resources that are highly tolerant to such conditions and to understand the mechanisms that contribute to its adaptations (Rollins et al., 2013).

The plant breeding seeking to increase yield requires conferring tolerance to abiotic stresses to the crops. These stresses are harmful in different regions of the world, and include drought, heat, excessive salt in soil, cold, flooding, toxic substances and lack of mineral nutrition (Ceccarelli, Grando, Baum, \& Udupa, 2015). The occurrence, severity, stage and duration of stresses varies within regions and within seasons. It rarely 
occurs isolate (Cattivelli et al., 2002) and are mainly harmful in semi-arid areas and prone to drought (Kishor, Rajesh, Reddy, Seiler, \& Sreenivasulu, 2014). As diseases, the abiotic stresses can be worsen due to global climatic changes. Therefore, working with abiotic stresses will require agronomic adaptation in each region, including sowing of different crops, or adaptation of the actual genotypes to new conditions (Cattivelli, Ceccarelli, Romagosa, \& Stanca, 2010).

Drought is the most important abiotic stress (Boyer \& Westgate, 2004), causing the greatest productivity losses, both in developed and developing countries (Cattivelli et al., 2010). In the last century, genetic gains in yields and genetic progress were lower in regions suffering from water stress (Slafer, Satorre, \& Andrade, 1994).

A key challenge is to improve drought tolerance without limiting yield potential, and QTLs for stressrelated traits coinciding with QTLs for productive potential should be considered as priority targets for the creation of new cultivars (Cattivelli et al., 2010).

The drought that occurs during the reproductive development of barley plants is especially relevant (Kishor et al., 2014), therefore, improving their tolerance to drought is essential. Fortunately, barley germplasm has a high degree of genetic variability for stress tolerance (Stanca et al., 2003).

Among such diversity, it is important to recognize the characteristics that could actually contribute to improving the performance of crops in the field. Not all strategies that are effective from an adaptive point of view, for the survival and successful reproduction of the individual, are suitable for reproduction (Levitt 1972; Mitra, 2001).

Environmental stress tolerance has often been described as a complex trait and, in fact, the molecular mechanisms of plant response to abiotic stresses are still unknown. This, along with the gap between laboratory and field research, could be an explanation for the delay in the development of drought tolerant varieties compared to other characteristics (Yang et al., 2010). However, single genes, such as those controlling flowering time, plant height, ear type and osmotic adjustment, may play important roles in adapting to stress-prone environments (Cattivelli et al., 2010).

There are examples of successful breeding for abiotic crop tolerance (Blum, 2011). It includes classical breeding (Rebetzke, Condon, Richards, \& Farquhar, 2002), by QTL introgression and marker-assisted selection (Courtois et al., 2003; Ribaut \& Ragot , 2007), or by altering the expression or transformation of unique genes; in a few occasions with beneficial effects in the field (Bahieldin et al., 2005; Hu et al., 2006; Xiao, Huang, Tang, \& Xiong, 2007). In the case of barley, water stress-related QTLs were identified by working with the mapping of populations under different environments (Teulat, Merah, Souyris, \& This, 2001; Baum et al., 2003; Biab et al., 2004; Talamé et al., 2004; Boudiar, Casas, Cantalapiedra, Gracia, \& Igartua, 2016) and through association mapping (Comadran et al., 2011; Wehner, Balko, Enders, Humbeck, \& Ordon, 2015).

However, the significant advantage in the field has not been demonstrated. In addition, the results of studies based on gene expression, proteomics or metabolomics, show different results depending on the plant material used, the tissue and stage of development evaluated, and the mode of application and magnitude of stress (Shaar-Moshe, Hübner, \& Peleg, 2015). However, there are some key processes that appear to be frequently involved in responses to hydric stress (i.e. thermal shock proteins and metabolism and abscisic acid signaling), and several fundamental signaling mechanisms are widely conserved among plant species (Nakashima, Yamaguchi-Shinozaki, \& Shinozaki, 2014; Gürel, Öztürk, Uçarlı, \& Rosellini, 2016). This could facilitate the transfer of the knowledge acquired in the model-plants to the cultivated species (Kishor et al., 2014).

A discrimination of susceptible and resistant genotypes is required to perform more detailed analyzes in order to improve stress tolerance. Disease-resistant genotypes are generally identified from the impact of screening on plants grown in the field, or by direct inoculation of isolated spores in greenhouse, both to test resistance to specific pathogens and to validate field results (Silvar et al., 2010; Vasudevan, Cruz, Gruissem, \& Bhullar, 2014).

For abiotic stresses, tolerant genotypes have been, as a tradition, empirically identified, and later by more sophisticated statistical analyzes based on phenotypes under stress. The more recent statistical approaches, which integrates environmental and genetic information into models, aims to identify the main variables to estimate the sensitivity and heritability of abiotic stress tolerance (Cattivelli et al., 2010).

In addition, new genome-editing techniques are stirring functional genetic research due to the ease of obtaining mutants for target genes with high specificity and accuracy, and even allowing the generation of transgene-free mutants in difficult-to-transform plant species (Zhang et al. 2010). Therefore, it represents an alternative to mutagenesis approaches, to standard breeding processes based on recombination, since it 
allows generating new allelic variants and for some genetic transformation purpose (Lawrenson et al., 2015).

Studies relating the identification of target genes, involved in the response to abiotic stresses, have been developed. Gene expression is a process by which information contained in a gene is translated into structures present in a particular cell type (mRNA or proteins). In multicellular organisms, the controlled gene expression regulates a genetic program fundamental for the embryonic development and differentiation of the individual.

Many events related to plant growth, development or even in response to various stimuli are the result of altered gene expression. Gene translation can be studied at protein level and from cell transcripts. The qualitative and quantitative determination of transcript levels of plant cells allows differentially expressed genes to be identified, and consequently their metabolic function can be investigated (Kuhn et al., 2001). The response of plants to stresses is very complex and involves the expression of many genes and pathways for various mechanisms and interactions with environments. Levels of osmo protective molecules usually increase during stress.

At the cellular level, changes in the expression of certain genes induce metabolic changes in response to stress factors. The transcription known as DREB (Dehydration Responsive Element Binding Protein) has been studied in several species against environmental stress conditions.

The DREB gene encodes a regulatory protein, the DREB protein, which is a transcription factor that is involved in the activation of other genes related to stress tolerance (Agarwal, Gupta, Lopato, \& Agarwal, 2017). Since it participates in the early stages of the process of perception and signaling, transcription factors end up regulating the expression of various groups of genes. This makes interesting the use of transcription factors in genetic engineering studies, where it is sought to improve characteristics of tolerance to stresses such as drought, salinity, and cold, among others.

DREB proteins act at the top of the chain of molecular events, inducing defense responses against cell dehydration. Genes homologous to this family have been identified in barley, canola, wheat and rice (OsDREB1A, OsDREB1B, OsDREB1C, OsDREB1D and OsDREB2A).

In the genetic-physiological context, genotypes adapted to stress conditions refer to the ability to produce adequately against these conditions (Bassett, 2013). However, in drought-tolerant genotypes, for example, they usually have higher production stability, but generally less productive potential (Fritsche-Neto \& Borém, 2011).

The knowledge of genetic diversity and its distribution in a species are useful both for the conservation of germplasm and for the identification of genetic materials that have characteristics of interest to be included in breeding programs.

The diversity available is represented by approximately 25,000 varieties in genetic stocks, currently maintained in several germplasm banks. In addition to these accessions, the collections have germplasm of the species with several genes of agronomic interest introduced from related species, including $H$. spontaneum, $H$. bulbosum, $H$. leporinum, $H$. murinum and $H$. chilense.

The germplasm is conserved in basic and active banks that are part of the International Board for Plant Genetic Resources (IDPGR) and Consultative Group of International Agriculture Research (CGIAR). Seed samples can be obtained from active banks in several countries, standing out the following:

United States: USDA Barley Collection, Small Grain Collection - USDA-ARS, Aberdeen, Idaho. It is the largest of all, including wild species and genetic stocks.

Canada: Canadian Barley Collection, Plant Gene Resources of Canada, Agriculture Canada. Ottawa, Ontario.

Japan: National Institute of Agricultural Sciences, Division of Genetics, Seed Storage Laboratory. Kannondai, Tsukuba-gun.

Russia: N. L Vavilov Institute of Plant Industry (VIR). Saint Petersburg

Germany: Zentral Institut fur Genetik und Kulturpflanzenforschung. Gaterlsleben, and Institut fur Pflanzenbau und Pflanzenzuchtung. Bundesforschungsanstalt fur Landwirtschaft. Braunschweig.

England: Institute of Plant Science Research (IPSR), Agricultural and Research Council (AFRC). Norwich, UK.

Syria: International Center for Agricultural Research in the Dry Areas (ICARDA). Aleppo.

Netherlands: Foundation for Agricultural Plant Breeding (SPV), Laboratory ofHaaf. Wageningen.

Mexico: Centro Internacional de Mejoramiento de Maiz y Trigo (CIMMYT). Ciudad de Mexico.

Brazil: Banco Ativo de Germoplasma de Cereais de Inverno, Embrapa Trigo, Passo Fundo, RS.

In detriment to the barley production, the genetic improvement is aimed at genotypes that meet, in 
quality and quantity, the demands of the brewing industry. Cultivars for animal or human feeding have been prioritized by few breeding programs (Mori \& Minella, 2012).

High performance, adequate quality and performance stability are the main priorities for breeding in the country. Thus, in breeding programs it is sought to combine in a new cultivar a set of morphological, physiological and industrial characteristics, which are visualized in the hypothetically ideal type of plant for the specific growing region, with characteristics of tolerance to environmental stresses.

Historically, the first generation of barley cultivars in Brazil was based on the introduction of cultivars and lineages from other countries that were evaluated for their performance. Within it, the selection of pure lines or heterogenous populations introduced was widely used, however, it was by the artificial hybridization (crosses), initiated in the late 50's, that modern cultivars were generated.

Currently, the development of cultivars for the brewing industry is based on selection in hybrid populations (crosses) developed in the country. As barley is self-polinated, the use of artificial hybridizations among previously selected genotypes has been reported for more than two centuries (Scheeren, Caierão, Silva, \& Bonow, 2012). This process consists of emasculation (removal of the anthers) in the heads of the designed maternal parent and pollination of these with pollen from the paternal parent (Minella, 1998). It is recognized that these processes were, and continue to be, the main responsible for the development of the great majority of the cultivars generated until today throughout the world. The crossbreeding between two parents $(A \times B)$ is the hybridization system commonly used in Brazil. However, it is known to be used the dual crosses $(A / B \times C / D)$ and triple $(A / B \times C)$ crosses (Borém, 1997)

Genetic improvement of winter cereals has advanced to the use of molecular markers for desirable traits in a breeding process. Studies with cereals presents use of molecular markers for assisted selection, for example the resistance to gibberella (Buerstmayr, Ban, \& Anderson, 2009), and drought tolerance (Gupta, Balyan, \& Gahlaut, 2017).

Quantitative Trait Loci (QTL) are regions of the genome responsible for the variation of a quantitative trait (Doeger, 2002). The identification of QTL consisting in looking for genomic regions that are associated to the control of quantitative characters. It means the searching for association between genotype and phenotype in a population with genetic variation. The identification of a QTL region does not necessarily lead to the recognition of a specific gene, since such a region may have dozens of genes (Liu, 1998; Broman \& Sen, 2009).

The mapping of QTL can lead to a better understanding of the inheritance of quantitative traits, as well as the correlation between these traits, since it is possible to estimate if this correlation is caused by linkage or pleiotropic effects. This information is important for the definition of breeding strategies, since the correlation caused by the linkage is transient and the correlation caused by pleiotropy is permanent. It is also possible to identify the chromosomal location of these QTLs, mode of action (additivity, dominance, heterosis and epistasis) and to unreel the genotype $x$ environment interaction for each QTL. In addition, it is possible to verify the stability of the QTL in different environments and provide important information for the use of this knowledge in the crop breeding (Carneiro \& Vieira, 2002).

Mapping QTL in experimental crosses can be an excellent initial approach to more complex investigations. The basic idea is to obtain phenotypic data in a progeny and to identify regions in the genome where the genotype of the marker can be associated with the phenotype of the individual (Broman \& Sen, 2009). Like other quantitative traits, resistance to environmental stresses may be associated with QTL. The great expectation regarding the mapping of QTL is that this technology can contribute to the understanding of genetic architecture and the nature of resistance to environmental stresses.

In general, the selection of genotypes adapted to stress conditions can be done directly (plants under stress), indirect (without imposition of stress) and combined. However, to be useful to the selection, the variables must have high heritability, ease of measurement and high correlation with the plant response to stress (Ferrão et al., 2016).

In order to select for abiotic stress conditions, physiological characteristics (stomatal conductance, photosynthetic capacity, plasmatic membrane composition, stomatal closure) may be used; morphological (leaf area, cuticle thickness, development of central vein, stomatal density); or morphoagronomics (root development, root/shoot ratio, anthesis-depth interval, stem size) (Bassett, 2013).

The choice of the plant breeding method to be used for selection of cultivars adapted to abiotic stress conditions is a preponderant factor, where it is necessary to consider the heritability and inheritance type of the most important characteristics, which should be studied previously. Among the different classical methods of breeding, the most commonly used for adaptation are genealogical (Fritsche Neto \& Borém, 2011). 
Tolerance to abiotic stresses is a quantitative trait controlled by many genes, with low heritability and high interaction between genotype and environment. The improvement of crops, mainly barley, aiming at tolerance to environmental stresses is still short approached in breeding programs, since the focus of breeding is focused on the industrial quality of this cereal. It presents a series of difficulties due to the interaction between abiotic factors such as water deficiency, temperature, irradiation, salinity, toxicity and / or nutrient deficiency, among others. In this sense, the breeding of barley plants has a wide path to go in order to improve the genotypes to maintain their high productivity, even in unfavorable climatic conditions.

\section{REFERENCES}

Agarwal, P. K., Gupta, K., Lopato, S., \& Agarwal, P. (2017). Dehydration responsive element binding transcription factors and their applications for the engineering of stress tolerance. Journal of Experimental Botany, 68(9), 2135-2148. https://doi.org/10.1093/jxb/erx118

Amabile, R. F., Capettini, F., \& Faleiro, F. G. (2013). BRS Savanna: New six-rowed malting barley cultivar for irrigated crops in the Brazilian Savanna. Crop Breeding and Applied Biotechnology, 13(2), 160-163. https://doi.org/10.1590/\$1984-70332013000200010

Amarante, L. do, Badinelli, D. dos S., Oliveira, M. L., Zenzen, I. L., Badinelli, P. G., \& Bernardi, E. (2007). Teores de Clorofilas em Soja Associada Simbioticamente com Diferentes Estirpes de. Revista Brasileira de Biociências, 5(supl 2), 906-908.

Apse, M. P., \& Blumwald, E. (2003). Engineering Salt Tolerance in Plants. Biotechnology and Genetic Engineering Reviews, 20(1), 261-276. https://doi.org/10.1080/02648725.2003.10648046

Arend, M. C., Pereira, J. O., \& Markoski, M. M. (2017). The CRISPR/Cas9 system and the possibility of genomic edition for cardiology. Arquivos Brasileiros de Cardiologia, 108(1), 81-83. https://doi.org/10.5935/abc.20160200

Badr, A., \& El-Shazly, H. (2012). Molecular approaches to origin, ancestry and domestication history of crop plants: Barley and clover as examples. Journal of Genetic Engineering and Biotechnology, 10(1), 1-12. https://doi.org/10.1016/j.jgeb.2011.08.002

Bahieldin, A., Mahfouz, H. T., Eissa, H. F., Saleh, O. M., Ramadan, A. M., Ahmed, I. A., ... Madkour, M. A. (2005). Field evaluation of transgenic wheat plants stably expressing the HVA1 gene for drought tolerance. Physiologia Plantarum, 123(4), 421-427. https://doi.org/10.1111/j.1399-3054.2005.00470.x

Bailey-Serres, J., \& Voesenek, L. A. C. J. (2008). Flooding stress: Acclimations and genetic diversity. Annual Review of Plant Biology, 59, 313-339. https://doi.org/10.1146/annurev.arplant.59.032607.092752

Bassett, C. L. (2013). Water Use and Drought Response in Cultivated and Wild Apples. Abiotic Stress - Plant Responses and Applications in Agriculture. https://doi.org/10.5772/55537

Baum, M., Grando, S., Backes, G., Jahoor, A., Sabbagh, A., \& Ceccarelli, S. (2003). QTLs for agronomic traits in the Mediterranean environment identified in recombinant inbred lines of the cross "Arta" $\mathrm{X} \mathrm{H}$. spontaneum 41-1. Theoretical and Applied Genetics, 107(7), 1215-1225. https://doi.org/10.1007/s00122-003-1357-2

Begg, J. E., \& Turner, N. C. (1975). Crop water déficits. Advance Agronomy, 27: 1-75. https://doi.org/10.1016/S0065-2113(08)60555-6

Bellucci, E., Bitocchi, E., Rau, D., Nanni, L., Ferradini, N., Giardini, A., ... Papa, R. (2013). Population structure of barley landrace populations and gene-flow with modern varieties. PLOS ONE, 8(12). https://doi.org/10.1371/journal.pone.0083891 
Bischoff, J., \& Werner, H. (1999). Salt Salinity Tolerance of Common Agricultural Crops in South Dakota: Forages and Grasses / Grains and Field Crops Forages and Grasses / Grains and Field Crops. Fact Sheets . Paper 83. Retrieved from http://openprairie.sdstate.edu/extension_fact/83

Blum, A. (2011). Plant breeding for water-limited environments. Plant Breeding for Water-Limited Environments. https://doi.org/10.1007/978-1-4419-7491-4

Boom, A., Serra-Majem, L., Ribas, L., Ngo, J., Pérez-Rodrigo, C., Aranceta, J., \& Fletcher, R. (2006). The contribution of ready-to-eat cereals to daily nutrient intake and breakfast quality in a mediterranean setting. Journal of the American College of Nutrition, 25(2), 135-143. https://doi.org/10.1080/07315724.2006.10719524

Borém, A. (1997). Melhoramento de Plantas. Viçosa, MG: Editora UFV.

Bothmer, V. R., Jacobsen, N., Baden, C., Jorgensen, R. B., \& Laursen, I. L. (1995). An ecogeographical study of the genus Hordeum: Systematic and ecogeographic studies on crop genepools 7 (2nd ed.). Rome, Italy: IPGRI.

Boudiar, R., Casas, A. M., Cantalapiedra, C. P., Gracia, M. P., \& Igartua, E. (2016). Identification of quantitative trait loci for agronomic traits contributed by a barley (Hordeum vulgare) Mediterranean landrace. Crop and Pasture Science, 67(1), 37-46. https://doi.org/10.1071/CP15149

Boyer, J. S., \& Westgate, M. E. (2004). Grain yields with limited water. Journal of Experimental Botany, 55(407), 2385-2394. https://doi.org/10.1093/jxb/erh219

Boyles, S. L., Anderson, V. L., \& Koch, K. B. (2017). Feeding barley to cattle. Columbus, Ohio: Ohio State University.

Buerstmayr, H., Ban, T., \& Anderson, J. A. (2009). QTL mapping and marker-assisted selection for Fusarium head blight resistance in wheat: A review. Plant Breeding, 128(1), 1-26. https://doi.org/10.1111/j.14390523.2008.01550.x

Cambraia, J. (2005). Aspectos bioquímicos, celulares e fisiológicos dos estresses nutricionais em plantas. In U. M. T. Nogueira, R. J. M. C., Araújo, E. L., Willadino, L. G., Cavalcante (Ed.), Estresses ambientais: danos e benefícios em plantas (pp. 95-105). Recife: Imprensa Universitária UFRPE.

Cantero, C, Villar, J. M., \& Fereres, E. (1989). Relaciones hídricas de genótipos de cereal de invierno en condiciones de secano semiárido em la Segarra. Riegos y Drenages, 29, 32-39.

Carneiro, M. S., \& Vieira, M. L. C. (2002). Mapas genéticos em plantas. Bragantia, 61(2), 89-100. https://doi.org/10.1590/s0006-87052002000200002

Cattivelli, L., Baldi, P., Crosatti, C., Grossi, M., Valè, G., \& Stanca, A. M. (2002). Genetic bases of barley physiological response to stressful conditions. In I. Slafer, G. A., Molina-Cano, J. L., Savin, R.., Araus, J. L., \& Romagosa (Ed.), Barley sciencei: recent advantages from molecular biology to agronomy of yield and qualità. New York, USA: Food Product Press.

Cattivelli, L., Ceccarelli, S., Romagosa, I., \& Stanca, M. (2010). Abiotic stresses in Barley: Problems and solutions. In E. Steven (Ed.), Barley: Production, Improvement, and Uses (pp. 282-306). Blackwell Publishing Ltd. https://doi.org/10.1002/9780470958636.ch10

Ceccarelli, S., Grando, S., Baum, M., \& Udupa, S. M. (2015). Breeding for drought resistance in a changing climate. Challenges and Strategies of Dryland Agriculture, (32), 167-190. https://doi.org/10.2135/cssaspecpub32.c11

Coelho, C. C. R., Neves, M. G., Oliveira, L. M., Conceição, A. G. C., Okumura, R. S., \& Oliveira-Neto, C. F. (2013). Biometria Em Plantas De Milho Submetidas Ao Alagamento. Revista Agroecossistemas, 5(1), 32. https://doi.org/10.18542/ragros.v5i1.1408 
Comadran, J., Russell, J. R., Booth, A., Pswarayi, A., Ceccarelli, S., Grando, S., ... Romagosa, I. (2011). Mixed model association scans of multi-environmental trial data reveal major loci controlling yield and yield related traits in hordeum vulgare in mediterranean environments. Theoretical and Applied Genetics, 122(7), 1363-1373. https://doi.org/10.1007/s00122-011-1537-4

CONAB - Companhia Nacional de Abastecimento. (2018). Acompanhamento da safra brasileira de grãos. V. 6 SAFRA 2018/19- N. 3 - Terceiro levantamento/dezembro 2018. CONAB. Retrieved from http://www.conab.gov.br/index.../16482_45de496aac454b837dd01c66c884650

CONAB - Companhia Nacional de Abastecimento. (2021). Acompanhamento da safra brasileira de grãos. V. 8 Safra 2020/21, N.6 - Sexto levantamento, 2021. CONAB. Retrieved from http://www.conab.gov.br/index.../16482_45de496aac454b837dd01c66c884650

Courtois, B., Shen, L., Petalcorin, W., Carandang, S., Mauleon, R., \& Li, Z. (2003). Locating QTLs controlling constitutive root traits in the rice population IAC $165 \times$ Co39. Euphytica, 134(3), 335-345. https://doi.org/10.1023/B:EUPH.0000004987.88718.d6

Craufurd, P. Q., Flower, D. J., \& Peacock, J. M. (1993). Effect of heat and drought stress on sorghum (Sorghum bicolor). I. Panicle development and leaf appearance. Experimental Agriculture, 29(1), 61-76. https://doi.org/10.1017/S0014479700020421

Dellagostin, S. M., Martinazzo, E. G., Pimentel-Junior, R., Troyjack, C., \& Pedó, T. (2017). Temperaturas extremas e qualidade fisiológica de sementes de plantas de lavoura. In F. A. Aumonde, T. Z., Pedó, T., Martinazzo, E. G., \& Villela (Ed.), Estresses Ambientais e a Produção De Sementes: Ciência e Aplicação (pp. 171-198). Pelotas, RS: Cópias Santa Cruz.

EMBRAPA - Empresa Brasileira de Pesquisa Agropecuária. (2005). Cultivo do Arroz Irrigado no Brasil Sistemas de Produção, 3. Pelotas, RS: Embrapa Clima Temperado.

Essemine, J., Ammar, S., \& Bouzid, S. (2010). Impact of heat stress on germination and growth in higher plants: physiological, biochemical and molecular repercussions and mechanisms of defence. Journal of Biological Sciences, 10(6): p.565-572. DOI: 10.3923 / jbs.2010.565.572John, E., Begg \& Neil, C ., T. C. (1967). CROP WATER DEFICITS. Angewandte Chemie International Edition, 6(11), 951-952.

FAO - Food and Agriculture Organization of the United Nations. (2000). Global network on integrated soil management for sustainable use of salt-affected soils. Rome, Italy. Retrieved from http://www.fao.org/home/en/

FAOSTAT - Food and Agriculture Organization of the United Nations. (2018). Statistical database. Food. agriculture organization of the United Nations. Rome, Italy. Retrieved from http://www.fao.org/faostat/en/\#home

Ferrão, R. G., Moreira, S. O., Ferrão, M. A. G., Riva, E. M., Arantes, L. O., Costa, A. F. S., ... Galvêas, P. A. O. (2016). Genética e melhoramento: desenvolvimento e recomendação de cultivares com tolerância à seca para o Espírito Santo. Incaper em Revista, 6(4), 51-71. Retrieved from https://ainfo.cnptia.embrapa.br/digital/bitstream/item/157824/1/Genetica-e-melhoramentodesenvolvimento-e-recomendacao.pdf

Ferrari, J. T. (2003). Incidência de Bipolaris sorokiniana nas sementes e a transmissão para plantas de cevada. Scientia Agraria, 4(1), 84. https://doi.org/10.5380/rsa.v4i1.1073

Ferreira, J. R., Pereira, J. F., Turchetto, C., Minella, E., Consoli, L., \& Delatorre, C. A. (2016). Assessment of genetic diversity in Brazilian barley using SSR markers. Genetics and Molecular Biology, 39(1), 86-96. https://doi.org/10.1590/1678-4685-GMB-2015-0148

Fritsche-Neto, R., \& Borém, A. (2011). Melhoramento de plantas para condições de estresses abióticos. Visconde do Rio Branco: Suprema. 
Galon, L., Tironi, S. P., Rocha, P. R. R., Concenço, G., Silva, A. F., Vargas, L., ... Ferreira, F. A. (2011). Habilidade Competitiva De Cultivares De Cevada Convivendo Com Azevém. Planta Daninha, 29(4), 771-781. https://doi.org/10.1590/S0100-83582011000400007

Gheyi, H. R. (2000). Problemas de salinidade na agricultura irrigada. In J. R. C. Oliveira, T. S., Assis-Junior, R. N., Romero, R. E., \& Silva (Ed.), Agricultura, sustentabilidade e o semiárido (pp. 329-346). Fortaleza, CE: Sociedade Brasileira de Ciências do Solo.

Guerrero, A. (1999). Cultivos herbáceos extensivos (6th ed.). Madrid, ES: Mundi prensa.

Gupta, P. K., Balyan, H. S., \& Gahlaut, V. (2017). QTL analysis for drought tolerance in wheat: Present status and future possibilities. Agronomy, 7(1), 1-21. https://doi.org/10.3390/agronomy7010005

Gürel, F., Öztürk, Z. N., Uçarlı, C., \& Rosellini, D. (2016). Barley genes as tools to confer abiotic stress tolerance in crops. Frontiers in Plant Science, 7(AUG2016). https://doi.org/10.3389/fpls.2016.01137

Houston, K., McKim, S. M., Comadran, J., Bonar, N., Druka, I., Uzrek, N., ... Waugha, R. (2013). Variation in the interaction between alleles of HVAPETALA2 and microRNA172 determines the density of grains on the barley inflorescence. Proceedings of the National Academy of Sciences of the United States of America, 110(41), 16675-16680. https://doi.org/10.1073/pnas.1311681110

Hu, H., Dai, M., Yao, J., Xiao, B., Li, X., Zhang, Q., \& Xiong, L. (2006). Overexpressing a NAM, ATAF, and CUC (NAC) transcription factor enhances drought resistance and salt tolerance in rice. Proceedings of the National Academy of Sciences of the United States of America, 103(35), 12987-12992. https://doi.org/10.1073/pnas.0604882103

Kellogg, E. A. (2001). Update on Evolution Evolutionary History of the Grasses 1. Plant Physiology, 125(March 2001), 1198-1205. Retrieved from http://www.plantphysiol.org

Kishor, P. B. K., Rajesh, K., Reddy, P. S., Seiler, C., \& Sreenivasulu, N. (2014). Drought stress tolerance mechanisms in barley and its relevance to cereals. Biotechnology in Agriculture and Forestry, 69, 161179. https://doi.org/10.1007/978-3-662-44406-1_9

Larcher, W. (2004). Ecofisiologia vegetal. São Carlos, SP: Rima Artes.

Lawrenson, T., Shorinola, O., Stacey, N., Li, C., Ostergaard, L., Patron, N., ... Harwood, W. (2015). Induction of targeted, heritable mutations in barley and Brassica oleracea using RNA-guided Cas9 nuclease. Genome Biology, 16(1), 1-13. https://doi.org/10.1186/s13059-015-0826-7

Lazzari, F. A. (1996). Recebimento, secagem e armazenagem de cevada cervejeira. Manhattan, Kansas State University

Liu, B. H. (1998). Statistical genomics: linkage, mapping and QTL analysis. New York, USA: CRC Press.

Loomis, R. S., \& Coonor, D. J. (1992). Crop Ecology: productivity and management in agricultural systems. Cambridge: Cambridge University Press.

Lopes, N. F., \& Lima, M. G. S. (2015). Fisiologia da produção. Viçosa, MG: Editora UFV.

Magalhães, J. A. (2011). A influência de características fenológicas na avaliação da tolerância à seca em sorgo. Circular técnica 165, Sete Lagoas, MG; Embrapa Milho e Sorgo.

MAPA - Ministério da Agricultura Pecuária e Abastecimento. (2020). PROJEÇÕES DO AGRONEGÓCIO Brasil 2019/20 a 2029/30 Projeções de Longo Prazo. Mapa - Ministério da Agricultura Pecuária e Abastecimento, 102.

Mayer, E. T., Fuke, G., Nörnberg, J. L., \& Minella, E. (2007). Caracterização nutricional de grãos integrais e descascados de cultivares de cevada. Pesquisa Agropecuária Brasileira, 42(11), 1635-1640. https://doi.org/10.1590/s0100-204×2007001100016 
Men, K., Duan, X., He, Z., Yang, Y., Yao, S., \& Wei, Y. (2017). CRISPR/Cas9-mediated correction of human genetic disease. Science China Life Sciences, 60(5), 447-457. https://doi.org/10.1007/s11427-017-90324

Minella, E. (2012). Árvore do conhecimento: cevada. Brasília, DF: Embrapa de Informação Tecnológica. Retrieved from https://www.agencia.cnptia.embrapa.br/gestor/cevada/Abertura.html

Minella, E. (1998). Hibridação em cevada. In A. Borém (Ed.), Hibridação artificial de plantas. Viçosa, MG: Editora UFV.

Mitra, J. (2001). Genetics and genetic improvement of drought resistance in crop plants. Current Science, 80(6), 758-763. Retrieved from https://www.jstor.org/stable/24105661?seq=1

Mittler, R. (2006). Abiotic stress, the field environment and stress combination. Trends in Plant Science, 11(1), 15-19. https://doi.org/10.1016/j.tplants.2005.11.002

Mori, C., \& Minella, E. (2012). Aspectos econômicos e conjunturais da cultura da cevada - Documentos on line 139. Passo Fundo, RS: Embrapa Trigo.

Muñoz-Amatriaín, M., Eichten, S. R., Wicker, T., Richmond, T. A., Mascher, M., Steuernagel, B., ... Stein, N. (2013). Distribution, functional impact, and origin mechanisms of copy number variation in the barley genome. Genome Biology, 14(6), 1-17. https://doi.org/10.1186/gb-2013-14-6-r58

Nakashima, K., Yamaguchi-Shinozaki, K., \& Shinozaki, K. (2014). The transcriptional regulatory network in the drought response and its crosstalk in abiotic stress responses including drought, cold, and heat. Frontiers in Plant Science, 5(MAY), 1-7. https://doi.org/10.3389/fpls.2014.00170

Narwal, S., Kumar, D., Kharub, A. S., \& Verma, R. P. S. (2020). Barley biofortification: present status and future prospects. Wheat and Barley Grain Biofortification. Elsevier Inc. https://doi.org/10.1016/b978-0-12818444-8.00011-0

Oscarsson, M., Andersson, R., Salomonsson, A. C., \& Åman, P. (1996). Chemical composition of barley samples focusing on dietary fibre components. Journal of Cereal Science, 24(2), 161-170. https://doi.org/10.1006/jcrs.1996.0049

Oukarroum, A., Madidi, S. El, Schansker, G., \& Strasser, R. J. (2007). Probing the responses of barley cultivars (Hordeum vulgare L.) by chlorophyll a fluorescence OLKJIP under drought stress and re-watering. Environmental and Experimental Botany, 60(3), 438-446. https://doi.org/10.1016/j.envexpbot.2007.01.002

Panizo-Casado, M., Déniz-Expósito, P., Rodríguez-Galdón, B., Afonso-Morales, D., Ríos-Mesa, D., Díaz-Romero, C., \& Rodríguez-Rodríguez, E. M. (2020). The chemical composition of barley grain (Hordeum vulgare L.) landraces from the Canary Islands. Journal of Food Science, 85(6), 1725-1734. https://doi.org/10.1111/1750-3841.15144

Pennisi, E. (2008). The blue revolution, drop by drop, gene by gene. Science, 320, 21-39. https://doi.org/10.1126 / science.320.5873.171

Poets, A. M., Fang, Z., Clegg, M. T., \& Morrell, P. L. (2015). Barley landraces are characterized by geographically heterogeneous genomic origins. Genome Biology, 16(1), 1-11. https://doi.org/10.1186/s13059-015-0712-3

Popinigis, F. (1985). Fisiologia de sementes (2nd ed.). Brasília, DF.

Poulsen, H. D., Blaabjerg, K., Norgaard, J. V., \& Ton Nu, M. A. (2012). High-moisture air-tight storage of barley and wheat improves nutrient digestibility. Journal of Animal Science, 90(SUPPL4), 242-244. https://doi.org/10.2527/jas.53985 
Prasad, P. V. V., Pisipati, S. R., Momčilović, I., \& Ristic, Z. (2011). Independent and Combined Effects of High Temperature and Drought Stress During Grain Filling on Plant Yield and Chloroplast EF-Tu Expression in Spring Wheat. Journal of Agronomy and Crop Science, 197(6), 430-441. https://doi.org/10.1111/j.1439037X.2011.00477.x

Rebetzke, G. J., Condon, A. G., Richards, R. A., \& Farquhar, G. D. (2002). Selection for reduced carbon isotope discrimination increases aerial biomass and grain yield of rainfed bread wheat. Crop Science, 42(3), 739745. https://doi.org/10.2135/cropsci2002.7390

Reid, D. A. (1976). Genetic potential for solving problems of soil mineral stress: aluminum and manganese toxicities in cereal grains. In M. J. Wright (Ed.), Plant adaptation to mineral stress in problem soils (pp. 564). Ithaca: Cornell University Press.

Ribaut, J. M., \& Ragot, M. (2007). Marker-assisted selection to improve drought adaptation in maize: The backcross approach, perspectives, limitations, and alternatives. Journal of Experimental Botany, 58(2), 351-360. https://doi.org/10.1093/jxb/erl214

Richardson, S. G., \& McCree, K. J. (1985). Carbon Balance and Water Relations of Sorghum Exposed to Salt and Water Stress. Plant Physiology, 79(4), 1015-1020. https://doi.org/10.1104/pp.79.4.1015

Rollins, J. A., Habte, E., Templer, S. E., Colby, T., Schmidt, J., \& Korff, M. (2013). Leaf proteome alterations in the context of physiological and morphological responses to drought and heat stress in barley (Hordeum vulgare L.). Journal of Experimental Botany, 64(11), 3201-3212. https://doi.org/10.1093/jxb/ert158

Rosa, T. D., Pedó, T., Martinazzo, E. G., Gehling, V. M., Aisenberg, G. R., Aumonde, T. Z., \& Villela, F. A. (2015). Alagamento do Solo: Efeito no Crescimento Inicial da Aveia Branca (Avena sativa L.). Scientia Agraria Paranaensis, 14(2), 127-131. https://doi.org/10.18188/1983-1471/sap.v14n2p127-131

Sachs, M., \& Vartapetian, B. (2007). Plant anaerobic stress I. Metabolic adaptation to oxygen deficiency. Plant Stress, 1(2), 123-135.

Savin, R., \& Nicolas, M. E. (1996). Effects of short periods of drought and high temperature on grain growth and starch accumulation of two malting barley cultivars. Australian Journal of Plant Physiology, 23(2), 201-210. https://doi.org/10.1071/PP9960201

Scheeren, P. L., Caierão, E., Silva, M. S., \& Bonow, S. (2012). Melhoramento de trigo no Brasil. In Trigo no Brasil (pp. 427-452). Sete Lagoas, MG: Embrapa Milho e Sorgo. Retrieved from www.cnpms.embrapa.br

Shaar-Moshe, L., Hübner, S., \& Peleg, Z. (2015). Identification of conserved drought-adaptive genes using a cross-species meta-analysis approach. BMC Plant Biology, 15(1), 1-18. https://doi.org/10.1186/s12870015-0493-6

Shanker, A., \& Venkateswarlu, B. (2011). Abiotic stress response in plants. Physiological, biochemical and genetic perspectives. https://doi.org/10.5772/1762

Silvar, C., Casas, A. M., Kopahnke, D., Habekuß, A., Schweizer, G., Gracia, M. P., ... Ordon, F. (2010). Screening the Spanish Barley Core Collection for disease resistance. Plant Breeding, 129(1), 45-52. https://doi.org/10.1111/j.1439-0523.2009.01700.x

Silveira, S. F.,Luz, V. K., Wolte, D. D., Santos, F. I. C., Viana, T. P., Fernandes, B. S., ... Oliveira, A. C. (2014). Response of oat seedlings to stress caused by acetic and butyric acids. Bragantia, 73(4), 345-356. https://doi.org/10.1590/1678-4499.166

Slafer, G. A., Satorre, E. H., \& Andrade, H. (1994). Increases in grain yield in bread wheat from breeding and associated physiological changes. In G. A. Slafer (Ed.), Genetic improvement of field crops (pp. 1-67). New York, USA: Marcel Dekker.

Slootmaker, L. A. J., \& Arzadun, J. F. (1969). Selection of young barley plants for tolerance to high soil acidity in relation with some agronomic characteristics of mature plants. Euphytica, 18(2), 157-162. https://doi.org/10.1007/BF00035686 
Soares, M. A. S., \& Machado, O. L. T. (2007). Defesa de plantas: sinalização química e espécies reativas de oxigênio. Revista Trópica: Ciências Agrárias e Biológicas, 1, 9-19.

Stanca, A. M., Romagosa, I., Takeda, K., Lundborg, T., Terzi, V., \& Cattivelli, L. (2003). Diversity in abiotic stresses. In K. Bothmer, R. V., Knüpffer, H., Hintum, T. V. \& Sato (Ed.), Diversity in Barley (Hordeum vulgare). Elsevier Science.

Szareski, V. J., Carvalho, I. R., Rosa, T. C., Dellagostin, S. M., de Pelegrin, A. J., Barbosa, M. H., ... Pegoraro, C. (2018). Wild Species: An Alternative for Rice Breeding under Abiotic Stress Conditions. American Journal of Plant Sciences, 09(06), 1093-1104. https://doi.org/10.4236/ajps.2018.96083

Taiz, L., \& Zeiger, E. (2009). Fisiologia vegetal (4th ed.). Porto Alegre, RS: ArtMed.

Tester, M., \& Davenport, R. (2003). Na+ tolerance and Na+ transport in higher plants. Annals of Botany, 91(5), 503-527. https://doi.org/10.1093/aob/mcg058

Teulat, B., Merah, O., Souyris, I., \& This, D. (2001). QTLs for agronomic traits from a Mediterranean barley progeny grown in several environments. Springer-Verlag, 103, 774-787. https://doi.org/https://doi.org/10.1007/s001220100619

Thomas, T. H., \& Fukai, S. (1995). Growth and yield response of barley and chickpea to water stress under three environments in southeast Queensland. I. Light interception, crop growth and grain yield. Crop and Pasture Science., 46, (1): 17-33. DOI: 10.1071 / AR9950035

Toppa, E. V. B., \& Brambilla, W. P. (2011). O melhoramento de plantas e a salinidade dos solos. Revista Verde de Agroecologia e Desenvolvimento Sustentável, 6(1), 21-25.

Troyjack, C., Szarescki, V. J., Martinazzo, E. G., Aumonde, T. Z., \& Pedó, T. (2017). Ecofisiologia, produção e qualidade de sementes de plantas de lavoura em resposta ao alagamento do solo e a restrição hídrica. In F. A. Aumonde, T. Z., Pedó, T., Martinazzo. E. G., \& Villela (Ed.), Estresses ambientais e a produção de sementes: cência e aplicação (pp. 139-169). Pelotas, RS: Cópias Santa Cruz.

Turchetto, C., Hartke, S., Caverzan, A., \& Turchetto-Zole, A. C. (2017). Enfoque molecular de estresses abióticos em plantas. In F. A. Aumonde, T. Z. Pedó, T. Martinazzo, E. G. Villela (Ed.), Estresses ambientais e a produção de sementes: ciência e aplicação. Pelotas, RS: Cópias Santa Cruz.

Ullrich, S. E. (2011). Significance, adaptation, production, and trade of barley. In S. E. Ullrich (Ed.), Barley: production, improvement and uses (pp. 3-13). Chichester, West Sussex, UK: Wiley- Blackwell.

Vasudevan, K., Cruz, C. M. V., Gruissem, W., \& Bhullar, N. K. (2014). Large scale germplasm screening for identification of novel rice blast resistance sources. Frontiers in Plant Science, 5(OCT), 1-9. https://doi.org/10.3389/fpls.2014.00505

Wang, W., Vinocur, B., \& Altman, A. (2003). Plant responses to drought, salinity and extreme temperatures: Towards genetic engineering for stress tolerance. Planta, 218(1), 1-14. https://doi.org/10.1007/s00425003-1105-5

Wang, X., Liu, T., Li, C., \& Chen, H. (2012). Effects of soil flooding on photosynthesis and growth of Zea mays L. seedlings under different light intensities. African Journal of Biotechnology, 11: 7676-7685. DOI: 10.5897 / AJB11.3345

Wehner, G. G., Balko, C. C., Enders, M. M., Humbeck, K. K., \& Ordon, F. F. (2015). Identification of genomic regions involved in tolerance to drought stress and drought stress induced leaf senescence in juvenile barley. BMC Plant Biology, 15(1). https://doi.org/10.1186/s12870-015-0524-3

Willadino, L., \& Camara, T. R. (2010). Tolerância das plantas à salinidade: aspectos fisiológicos e bioquímicos. Enciclopédia Biosfera, 6(11), 1-23.

Xiao, B., Huang, Y., Tang, N., \& Xiong, L. (2007). Over-expression of a LEA gene in rice improves drought resistance under the field conditions. Theoretical and Applied Genetics, 115(1), 35-46. https://doi.org/10.1007/s00122-007-0538-9 
Yordanova, R. Y., \& Popova, L. P. (2001). Photosynthetc response of barley plants to soil flooding. Photosynthetica, 39(4), 515-520.

Zabalza, A., Dongen, J. T., Froehlich, A., Oliver, S. N., Faix, B., Gupta, K. J., ... Geigenberger, P. (2009). Regulation of respiration and fermentation to control the plant internal oxygen concentration. Plant Physiology, 149(2), 1087-1098. https://doi.org/10.1104/pp.108.129288

Zhang, H., Irving, L. J., McGill, C., Matthew, C., Zhou, D., \& Kemp, P. (2010). The effects of salinity and osmotic stress on barley germination rate: Sodium as an osmotic regulator. Annals of Botany, 106(6), 10271035. https://doi.org/10.1093/aob/mcq204

Received: January 21, 2021.

Accepted: March 24, 2021.

Published: May 5, 2021.

\section{English by: Giordano Gelain Conte}

